\title{
Prospective double-blind trial of synthetic steroid (Org OD 14) for preventing postmenopausal osteoporosis
}

\author{
ROBERT LINDSAY，DAVID MCK HART，ANDREW KRASZEWSKI
}

\section{Summary and conclusions}

A double-blind trial of Org OD 14, a synthetic steroid with an unusual endocrine profile, was conducted on 100 postmenopausal women; of these, 63 completed two years' treatment (33 Org OD 14; 30 placebo). A dose of 2.5 $\mathrm{mg} /$ day successfully prevented bone loss over two years, whereas a significant reduction in bone mineral content occurred in women taking placebo, the rate being comparable to that in earlier studies $(p<0.01)$. At the dosage used (2.5 mg/day) Org OD 14 also significantly reduced the severity of menopausal complaints (flushing, sweating, etc). Vabra aspiration curettage in 20 cases 6-18 months after starting active treatment showed no evidence of endometrial hyperplasia, though weak proliferation of the endometrium was seen in three.

Org OD 14 may provide a new approach to hormonal prevention of bone loss in postmenopausal women without inducing appreciable endometrial stimulation; the potential value of Org OD 14 in osteoporosis and other post-climacteric complaints warrants further investigation.

\section{Introduction}

Oestrogenic compounds prevent the loss of bone that occurs after a natural or surgically induced menopause. ${ }^{1-3}$ Nevertheless, from prospective studies effective prophylaxis against the clinical sequelae of osteoporosis (basically fracture of axial or peripheral skeleton) requires long-term treatment with oestrogen, ${ }^{4}$ which may be hazardous. Women given oestrogens apparently have a definitely increased risk of developing endometrial hyperplasia and carcinoma unless enough progestogen is added to the regimen, ${ }^{5-7}$ and although progestogens themselves may offer some protection against bone loss, ${ }^{8}$ no data are available on the effect of combined preparations on osteoporosis or its rate of development. There is also little prospective evidence about the relation of such preparations to the incidence of vascular disease in postmenopausal women. ${ }^{9}$

To avert such complications, particularly endometrial neoplasm, we have examined the effect on bone of the synthetic steroid Org OD $14((7 \alpha, 17 \alpha)$-17-hydroxy-7-methyl-19-norpregn5(10)-en-20-yn-3-one). In animal experiments this compound has weak progestational, weak oestrogenic, very weak androgenic, and clear anabolic activity (research files, Oss, Organon).

\section{Patients and methods}

One hundred and twenty-seven women referred consecutively to a menopause clinic were assessed for treatment. All complained of

\footnotetext{
Western Infirmary, Glasgow G11 6NT

ROBERT LINDSAY, PHD, MRCP, lecturer in medicine (present address: Department of Medicine, College of Physicians and Surgeons, Columbia University, 630 West 168th Street, New York, NY 10032)

Stobhill Hospital, Glasgow G21 3UW

DAVID MCK HART, MD, FRCOG, consultant in obstetrics and gynaecology ANDREW KRASZEWSKI, MRCOG, senior registrar in obstetrics and gynaecology (present appointment: consultant in obstetrics and gynaecology, Rutherglen Maternity and Royal Samaritan hospitals, Glasgow)
}

menopausal symptoms, hot flushes or night sweats being prominent. Fifteen patients were excluded from the trial because of contraindications to oestrogen treatment, coexistent disease at the first clinic visit, or previous oestrogen treatment. A further 12 did not wish to continue after the trial procedure had been explained. The remaining 100 patients were given in predetermined randomised order either Org OD 14, 2.5 mg twice daily, or an identical placebo. All patients agreed to participate in the therapeutic trial of a drug that might prevent bone loss and alleviate symptoms. The protocol was approved by the ethical committees of the participating institutions before the study began.

After three months, when 25 patients had been admitted, three patients had single episodes of uterine bleeding. The dose of Org OD 14 was subsequently reduced to $2.5 \mathrm{mg}$ daily (two $1.25 \mathrm{mg}$ tablets) for all patients.

Samples of venous blood and urine were obtained from each patient fasting, at the start of treatment, and six-monthly thereafter. Bone mineral content was measured at the midpoint of the third right metacarpal at the start of treatment and at six-month intervals by photon absorptiometry. At the start of treatment and at yearly intervals mineral content was estimated by $x$-ray densitometry. Both techniques have been described. ${ }^{10-12}$

Biochemical measurements in serum and urine were performed by standard techniques. Calcium concentrations were estimated by atomic absorption spectrophotometry. ${ }^{13}$ Standard AutoAnalyzer methods were used to estimate creatinine (N 11) and phosphorus (N 4) concentrations and activities of alanine and aspartate transaminases (N 44). Serum alkaline phosphatase activity was estimated by the technique of King and Wooton. ${ }^{14}$ Urinary hydroxyproline concentrations were measured by the method of Stegemann and Stalder. ${ }^{15}$

\section{Results}

Of the 100 women who remained in the study, 63 completed two years' treatment. Nineteen had had bilateral oophorectomy, of whom nine received Org OD 14 (by chance). The median time from menopause (or oophorectomy) was 14.4 months (range 6-36 months). Eight patients were removed from the trial because of intercurrent illness. Fifteen patients taking placebo complained that their symptoms were not controlled by the treatment and were withdrawn and given standard oestrogen-progestogen treatment. Three patients taking Org OD 14 were removed from the trial for similar reasons. Eleven patients (eight taking Org OD 14, three taking placebo) defaulted for "non-medical" reasons (leaving the area, loss of interest, etc). All were contacted for confirmation of reasons for defaulting and current state of health. There were no clinical cardiovascular events apart from a cerebrovascular accident in a patient taking placebo.

Global assessment of menopausal symptoms with the Blatt Menopausal Index ${ }^{16}$ and assessment of the incidence of flushing and sweating attacks showed better control in the Org OD 14 group, although there was a highly significant placebo response (Lindsay and Hart, unpublished data).

Initial measurements-Table I gives the physical characteristics and initial bone mineral states of women in the Org OD 14, placebo, and defaulter groups. The first two groups therefore include only patients who completed two years of treatment. No significant differences were found between the groups, and the results of bone mineral estimations by photon absorptiometry and $x$-ray densitometry agreed closely with our observations on other groups. ${ }^{1-8}$ We therefore regarded each group as representative not only of the total sample but of all women attending our clinic.

Bone mineral changes-During the two years of follow-up the placebo group lost bone at a rate of $3.6 \%(1.6 \mathrm{mg} / \mathrm{mm})$.yearly. This rate was equivalent to that found in our studies on placebo-treated oophorectomised patients and a mixed group of oophorectomised and postmenopausal patients ${ }^{18}$ and confirms that bone loss is more pronounced in the period immediately after a natural menopause or oophorectomy. ${ }^{1}$ In contrast (table II) the group given Org OD 14 showed no net bone 
loss, and over the two years there was a small but not significant gain in mineral content $(0.05 \mathrm{mg} / \mathrm{mm})$. In our experience of treating mixed groups of patients with an interval between oophorectomy or the menopause and the onset of treatment this is the maximum response obtainable. $X$-ray densitometry gave similar results (table II).

Biochemical responses-During the trial significant reductions in fasting concentrations of serum and urinary calcium, serum phosphate, and urinary hydroxyproline occurred in the Org OD 14 group (table III), and these concentrations remained significantly below the mean values in the placebo-treated group at each six-month measurement $(\mathrm{p}<0.01$ in all cases). A slight reduction in serum alkaline phosphatase activity was observed at six and 18 months $(p<0.01)$ but not at 12 or 24 months; this was a less significant change than that observed in our trial of mestranol ${ }^{1}$ (mean daily dose $24.9 \mu \mathrm{g}$ ). The reduction in the urinary calcium to creatinine ratio, however, was equal to that produced by mestranol or conjugated equine oestrogen. ${ }^{2}$

Liver function-Two patients in the Org OD 14 group showed time-dependent increments in alanine and aspartate transaminase activities during the study. No such changes occurred in the placebo group. Without breaking the code both patients were removed from the trial and their treatment discontinued. The patients were followed up, and both sets of values returned to normal over a few months. One patient admitted to a high alcohol intake, and liver biopsy in the second case showed minimal changes compatible with non-progressive chronic active hepatitis; enzyme changes returned and smooth-muscle antibody was detected one year later. Detailed study of transaminase values in all patients in the trial showed no evidence of a significant drug-induced change.
Endometrial changes-It was too soon to assess all the data on endometrial changes, which will therefore be reported separately. By the time of this analysis, however, 20 patients treated with Org OD 14 continuously for 12-24 months had undergone biopsy by Vabra aspiration curettage. In 17 cases no endometrium was obtained. Two specimens showed minimal proliferative changes, and one more definite evidence of endometrial proliferation; no evidence of hyperplasia was detected in any sample. These results were similar to those in our studies on untreated postmenopausal women and unlike our findings with unopposed oestrogen or those quoted for such compounds. ${ }^{17}$ In the three patients who had had vaginal bleeding while taking the higher dose of Org OD 14 subsequent curettage was normal.

Other side effects-Two patients complained of an acneiform rash on their upper backs during treatment, but there were no other signs of virilisation. Several women in the active-treatment group commented on mood elevation and improved concentration, but this was not documented in a way suitable for analysis.

\section{Discussion}

A decrease in bone mass occurs in many postmenopausal women and may be prevented with oestrogen. ${ }^{1-3}$ Early identification of bone loss may be obtained by only a few techniques with any accuracy. ${ }^{18}$ Photon absorptiometry and radiography of a peripheral bone (metacarpal, radius, or ulna) are most com-

TABLE I-Initial measurements of patients included in trial. Org OD 14 and placebo groups include only patients treated for two full years. All others, irrespective of treatment, are included in defaulter group

\begin{tabular}{|c|c|c|c|c|c|c|c|}
\hline Group & $\begin{array}{c}\text { No } \\
\text { of women }\end{array}$ & $\begin{array}{c}\text { No } \\
\text { oophorectomised }\end{array}$ & $\begin{array}{c}\text { Age } \\
\text { (years) }\end{array}$ & $\begin{array}{c}\text { Weight } \\
(\mathbf{k g})\end{array}$ & $\underset{(\mathrm{cm})}{\text { Height }}$ & $\begin{array}{l}\text { Metacarpal mineral } \\
(\mathrm{mg} / \mathrm{mm})^{*}\end{array}$ & $\begin{array}{l}\text { Whole-bone density } \\
\text { (percentile) } \dagger\end{array}$ \\
\hline $\begin{array}{l}\text { Org OD } 14 \\
\text { Placebo } \\
\text { Defaulter }\end{array}$ & $\begin{array}{l}33 \\
30 \\
37\end{array}$ & $\begin{array}{l}8 \\
9 \\
2\end{array}$ & $\begin{array}{l}49.6 \pm 0.6 \\
49.6 \pm 0.7 \\
49.4 \pm 0.6\end{array}$ & $\begin{array}{l}60 \cdot 4 \pm 1 \cdot 4 \\
63.3 \pm 1.4 \\
61.8 \pm 2 \cdot 2\end{array}$ & $\begin{array}{l}159 \cdot 0 \pm 1 \cdot 2 \\
160 \cdot 5 \pm 1 \cdot 1 \\
160 \cdot 0 \pm 1 \cdot 1\end{array}$ & $\begin{array}{l}44 \cdot 0 \pm 1 \cdot 2 \\
43.9 \pm 1 \cdot 2 \\
45 \cdot 0 \pm 1 \cdot 4\end{array}$ & $\begin{array}{l}46 \pm 6 \\
48 \pm 7 \\
47 \pm 6\end{array}$ \\
\hline
\end{tabular}

Photon absorptiometry.

†Radiography (expected mean $50 \%$ ).

TABLE II-Changes in bone mineral content during trial (means $\pm S E M$ )

\begin{tabular}{|c|c|c|c|c|c|}
\hline & \multicolumn{5}{|c|}{ Treatment period (months) } \\
\hline group & 0 & 6 & 12 & 18 & 24 \\
\hline $\begin{array}{ll}\text { Photon absorptiometry }(\mathrm{mg} / \mathrm{mm}) * & \left\{\begin{array}{l}\text { Org OD } 14 \\
\text { Placebo }\end{array}\right. \\
X \text {-ray densitometry (SAE mm Al } / \mathrm{mm}) *\left\{\begin{array}{l}\text { Org OD } 14 \\
\text { Placebo }\end{array}\right.\end{array}$ & $\begin{array}{l}44 \cdot 0 \pm 1 \cdot 2 \\
43 \cdot 9 \pm 1 \cdot 2 \\
\text { NS } \\
33.9 \pm 1 \cdot 2 \\
33 \cdot 1 \pm 0.8 \\
\text { NS }\end{array}$ & $\begin{array}{l}43 \cdot 2 \pm 1 \cdot 0 \\
41 \cdot 7 \pm 1 \cdot 2 \\
\mathrm{NS}\end{array}$ & $\begin{array}{l}43 \cdot 9 \pm 1 \cdot 2 \\
40 \cdot 8 \pm 1 \cdot 1 \\
\mathrm{p}<0 \cdot 05 \\
32 \cdot 8 \pm 1 \cdot 2 \\
31 \cdot 1 \pm 0.9 \\
\text { NS }\end{array}$ & $\begin{array}{c}44.1 \pm 1.0 \\
40.6 \pm 1.0 \\
p<0.01\end{array}$ & $\begin{array}{l}44 \cdot 5 \pm 1 \cdot 0 \\
39 \cdot 7 \pm 1 \cdot 0 \\
p<0 \cdot 001 \\
34 \cdot 1 \pm 1 \cdot 2 \\
29 \cdot 9 \pm 0.9 \\
p<0.01\end{array}$ \\
\hline
\end{tabular}

NS $=$ Not significant

For methods see references $10-12$.

TABLE III-Changes in biochemical values during trial (means $\pm S E M$ )

\begin{tabular}{|c|c|c|c|c|c|c|}
\hline & \multirow{2}{*}{$\begin{array}{l}\text { Treatment } \\
\text { group }\end{array}$} & \multicolumn{5}{|c|}{ Treatment period (months) } \\
\hline & & 0 & 6 & 12 & 18 & 24 \\
\hline Serum calcium (mmol/l) & $\left\{\begin{array}{l}\text { Org OD } 14 \\
\text { Placebo }\end{array}\right.$ & $\begin{array}{l}2.44 \pm 0.02 \\
2 \cdot 40 \pm 0.02 \\
\text { NS }\end{array}$ & $\begin{array}{l}2.34 \pm 0.021^{*} \\
2.41 \pm 0.018 \\
\mathrm{p}<0.01\end{array}$ & $\begin{array}{c}2.36 \pm 0.018 \\
2.40 \pm 0.015 \\
p<0.05\end{array}$ & $\begin{array}{l}2 \cdot 35 \pm 0.022 \\
2 \cdot 36 \pm 0.025 \\
\text { NS }\end{array}$ & $\begin{array}{l}2 \cdot 38 \pm 0.021 \\
2 \cdot 38 \pm 0.025 \\
\text { NS }\end{array}$ \\
\hline Serum phosphate (mmol/l) & $\left\{\begin{array}{l}\text { Org OD } 14 \\
\text { Placebo }\end{array}\right.$ & $\begin{array}{l}1.23 \pm 0.03 \\
1.22 \pm 0.03 \\
\mathrm{NS}\end{array}$ & $\begin{array}{c}1.07 \pm 0.04^{*} \\
1.23 \pm 0.03 \\
p<0.01\end{array}$ & $\begin{array}{c}1.08 \pm 0.03^{*} \\
1.21 \pm 0.03 \\
p<0.01\end{array}$ & $\begin{array}{c}1.12 \pm 0.04 * \\
1.24 \pm 0.03 \\
p<0.05\end{array}$ & $\begin{array}{c}1.13 \pm 0.03^{*} \\
1.23 \pm 0.03 \\
p<0.05\end{array}$ \\
\hline Alkaline phosphatase (KA units) & $\left\{\begin{array}{l}\text { Org OD } 14 \\
\text { Placebo }\end{array}\right.$ & $\begin{array}{l}8.63 \pm 0.53 \\
8.66 \pm 0.47 \\
\quad \text { NS }\end{array}$ & $\begin{array}{c}7.73 \pm 0.55^{*} \\
9.30 \pm 0.60 \\
\mathrm{p}<0.01\end{array}$ & $\begin{array}{c}8.27 \pm 0.63 \\
8.85 \pm 0.59 \\
\text { NS }\end{array}$ & $\begin{array}{l}7.62 \pm 0.64^{*} \\
9.32 \pm 0.70 \\
p<0.01\end{array}$ & $\begin{array}{c}8.52 \pm 0.73 \\
9 \cdot 77 \pm 0.61 \\
\text { NS }\end{array}$ \\
\hline Calcium/creatinine (mmol/mmol) & $\left\{\begin{array}{l}\text { Org OD } 14 \\
\text { Placebo }\end{array}\right.$ & $\begin{array}{c}0.048 \pm 0.004 \\
0.050 \pm 0.004 \\
\text { NS }\end{array}$ & $\begin{array}{l}0.025 \pm 0.003^{*} \\
0.047 \pm 0.005 \\
\mathrm{p}<0.005\end{array}$ & $\begin{array}{c}0.029 \pm 0.004^{*} \\
0.043 \pm 0.005 \\
\mathrm{p}<0.01\end{array}$ & $\begin{array}{c}0.024 \pm 0.004^{*} \\
0.054 \pm 0.008 \\
\mathrm{p}<0.001\end{array}$ & $\begin{array}{c}0.022 \pm 0.003^{*} \\
0.055 \pm 0.006 \\
\mathrm{p}<0.001\end{array}$ \\
\hline Hydroxyproline/creatinine ( $\mathrm{mmol} / \mathrm{mmol})\{$ & $\left\{\begin{array}{l}\text { Org OD } 14 \\
\text { Placebo }\end{array}\right.$ & $\begin{array}{c}0.0285 \pm 0.0017 \\
0.0284 \pm 0.0016 \\
\text { NS }\end{array}$ & $\begin{array}{c}0.022 \pm 0.0015^{*} \\
0.0256 \pm 0.002 \\
\mathrm{p}<0.01\end{array}$ & $\begin{array}{c}0.022 \pm 0.0019 * \\
0.0325 \pm 0.003 \\
\mathrm{p}<0.001\end{array}$ & $\begin{array}{c}0.0251 \pm 0.003^{*} \\
0.0340 \pm 0.0038 \\
\mathrm{p}<0.005\end{array}$ & $\begin{array}{c}0.0222 \pm 0.0024 * \\
0.0354 \pm 0.0024 \\
\mathrm{p}<0.001\end{array}$ \\
\hline
\end{tabular}

- Significantly different from value at time 0 (p<0.01; paired $t$ test). Conversion: $S I$ to traditional units CCalcium: $1 \mathrm{mmol} / 1 \approx 4.0 \mathrm{mg} / 100 \mathrm{ml}$. Phosphate: $1 \mathrm{mmol} / 1 \approx 3.01 \mathrm{mg} / 100 \mathrm{ml}$. Calcium/creatinine: $1 \mathrm{mmol} / \mathrm{mmol} \approx 2.8 \mathrm{mg} / \mathrm{mg}$. Hydroxy-
proline $/$ creatinine: $1 \mathrm{mmol} / \mathrm{mmol} \approx 0.86 \mathrm{mg} / \mathrm{mg}$. 
monly used. ${ }^{18}$ Although not entirely reliable for identifying individual patients with early osteopenia, the methods have been applied with considerable success to groups $^{1-3}$ in therapeutic trials. We found a high correlation between changes in metacarpal bone and radius, ${ }^{19}$ which was shown to have a close relation to total body calcium. ${ }^{18}$ Cadaver studies confirmed interrelations between sites, ${ }^{20}$ including the vertebrae, where collapse is pathognomonic in postmenopausal osteoporosis. Evidence that such oestrogen-induced changes in peripheral skeletal density protect against fracture is supported by retrospective ${ }^{2122}$ and case-control studies. ${ }^{23}$

Prevention of bone loss may not be specific to the oestrogenic class of steroid, and that a progestogen also prevents bone loss supports this hypothesis. ${ }^{8}$ Since oestrogen stimulates endometrial growth and, when given continuously and unopposed, may contribute to endometrial carcinoma, a progestogen must be included in the regimen either in combination or as a sequential preparation; this is particularly important, since to be effective treatment would probably need to be given over a long period. ${ }^{4}$ An acceptable alternative would be a preventive treatment that had minimal or no effect on endometrium. Calcium supplements may be partially successful ${ }^{2}{ }^{3}$ but are apparently less effective than oestrogen in preventing bone loss. ${ }^{2}$ 3 Oestriol, which has little effect on the uterus, has only minimal effects on bone in clinical doses. ${ }^{24}$

Org OD 14 seems to fulfil several of these criteria. In our study effective prevention of bone loss was achieved with $2.5 \mathrm{mg}$ daily. At this dose there was no postmenopausal bleeding and no evidence of endometrial hyperplasia. Satisfactory control of menopausal symptoms was obtained in most patients.

Biochemically the compound appears to exert its effect on bone by a mechanism similar to that of oestrogens. The reduction in serum alkaline phosphatase activity and urinary hydroxyproline concentration suggests a reduced bone turnover rate and was qualitatively similar to that observed with oestrogen, ${ }^{12}$ although the changes were somewhat less pronounced during treatment with Org OD 14 than during treatment with mestranol (average dose $25 \mu \mathrm{g} /$ day). Nevertheless, the protective effects of Org OD 14 on bone were unequivocal, and in this respect it was as effective as any true oestrogen we have examined. We did not include a positive control group in this trial for logistical reasons, but such a study of Org OD 14 against a standard oestrogen preparation would be useful. In any case, further investigation of Org OD 14 is required to see whether a lower daily dose will be effective in preventing bone loss. Certainly with the apparent lack of effect on endometrium, together with its efficacy with respect to bone, compounds such as Org OD 14 warrant consideration for long-term prevention of postmenopausal bone loss.

Org OD $14 \quad 1.25 \mathrm{mg}$ and matching placebo tablets were kindly supplied by Organon Laboratories Limited.

Requests for reprints should be sent to Dr David McK Hart.

\section{References}

${ }^{1}$ Lindsay R, Hart DM, Aitken JM, MacDonald EB, Anderson JB, Clarke AC. Long-term prevention of postmenopausal osteoporosis by oestrogen. Lancet $1976 ; \mathrm{i}: 1038-41$.

${ }^{2}$ Recker RR, Saville PD, Heaney RP. Effect of estrogens and calcium carbonate on bone loss in postmenopausal women. Ann Intern Med $1977 ; 87: 649-55$.

3 Horsman A, Gallagher JC, Simpson M, Nordin BE. Prospective trial of oestrogen and calcium in postmenopausal women. $\mathrm{Br} \mathrm{Med} \mathcal{F} 1977$;ii: 789-92.

4 Lindsay R, Hart DM, MacLean A, Clark AC, Kraszewski A, Garwood J. Bone response to termination of oestrogen treatment. Lancet $1978 ; \mathrm{i}$ : 1325-7.

5 Ziel HK, Finkle WD. Increased risk of endometrial carcinoma among users of conjugated estrogens. $N$ Engl f Med $1975 ; 293: 1167-70$.

6 Campbell S, Whitehead MI. The endometrium in the menopause. In: Van Keep PA, Serr DM, Greenblatt RB, eds. Female and male climacteric: current opinion 1979. Lancaster: MTP Press, 1979:111-20.

7 Gambrell RD Jr. The prevention of endometrial cancer in postmenopausal women with progestogens. Maturitas 1978;1:107-12.
${ }^{8}$ Lindsay R, Hart DM, Purdie D, Ferguson MM, Clark AS, Kraszewski A. Comparative effects of oestrogen and a progestogen on bone loss in postmenopausal women. Clin Sci Mol Med 1978;54:193-5.

- Hart DM, Lindsay R, Purdie D. Vascular complications of long-term oestrogen therapy. In : Lauritzen C, Van Keep PA, eds. Estrogen therapy: the benefits and risks. Basle: Karger, 1978:174-91. (Front Horm Res, 5.)

10 Shimmins J, Anderson JB, Smith DA, Aitken M. The accuracy and reproducibility of bone mineral measurements "in vivo": (a) the measurement of metacarpal mineralisation using an $x$-ray generator. Clin Radiol 1972;23:42-6.

11 Shimmins J, Smith DA, Aitken M, Anderson JB, Gillespie FC. The accuracy and reproducibility of bone mineral measurements "in vivo": (b) methods using sealed isotope sources. Clin Radiol 1972;23:47-51.

12 Lindsay R, Anderson JB. Radiological determination of changes in bone mineral content. Radiography 1978;44:21-6.

13 Trudeau DL, Freier EF. Determination of calcium in urine and serum by atomic absorption spectrophotometry (AAS). Clin Chem 1967;13:101-14.

14 King EJ, Wooton ID. Microanalysis in medical biochemistry. London: Churchill, 1956.

15 Stegemann H, Stalder K. Determination of hydroxyproline. Clin Chim Acta $1967 ; 18: 267-73$.

${ }^{16}$ Blatt MH, Wiesbader H, Kupperman HS. Vitamin $\mathrm{E}$ and climacteric syndrome: failure of effective control as measured by menopausal index. Arch Intern Med 1953;91:792-9.

17 Sturdee DW, Wade-Evans T, Paterson ME, Thom M, Studd JW. Relations between bleeding pattern, endometrial histology, and oestrogen treatment in menopausal women. $\mathrm{Br}$ Med $\mathcal{f} 1978$;i:1575-7.

${ }^{18}$ Cohn SH, Aloia JF, Letteri JM. Noninvasive measurements of bone mass and their clinical significance. Calcif Tissue Res 1978;26:1-3.

19 Lindsay R, Hart DM, MacLean A, et al. Pathogenesis and prevention of postmenopausal osteoporosis. In: Cooke ID, ed. The role of estrogen/ progestogen in the management of the menopause. Lancaster: MTP Press, 1978;9-27.

${ }^{20}$ Aitken JM, Smith CB, Horton PW, Clark DL, Boyd JF, Smith DA. The interrelationships between bone mineral at different skeletal sites in male and female cadavera. $f$ Bone foint Surg $[B r] 1974 ; 56: 370-5$.

21 Wallach S, Henneman PH. Prolonged estrogen therapy in postmenopausal women. FAMA 1959;171:1637-42.

22 Gordan GS, Picchi J, Roof BS. Antifracture efficacy of long-term estrogens for osteoporosis. Trans Assoc Am Physicians 1973;86:326-32.

${ }^{23}$ Hutchinson TA, Polansky SM, Feinstein AR. Post-menopausal oestrogens protect against fractures of hip and distal radius: a case-control study. Lancet 1979 ;ii:707-9.

${ }^{24}$ Lindsay R, Hart DM, MacLean A, Garwood J, Clark AC, Kraszewski A. Bone loss during oestriol therapy in postmenopausal women. Maturitas $1979 ; 1: 279-85$.

(Accepted 3 December 1979)

ONE HUNDRED YEARS AGO The following interesting case, recorded by Professor H. Fischer in the Deutsche Med Wochenschrift, October 25 th, 1879 , is compared by Dr Napier with one communicated to the Glasgow Medical fournal in 1879, p 222, by Dr Dove M'Calman. The patient, an old lady, consulted Dr Fischer for a peculiar skineruption of six months' standing, partly vesicular and partly squamous, closely resembling scabies, distributed over nearly the whole of the body, but most marked on the forearm, legs, and back. She brought with her a little box full of limbs and other portions of an insect, which she stated she had scratched out of a number of small bladder-like elevations which had appeared on the skin at various parts of the body; the formation of these vesicles was attended by unbearable and persistent itching. The insects were usually alive when taken out, and soon took wing and flew off. The patient was a well educated and nonhysterical lady, and her extraordinary story was fully corroborated by her husband and relations; she was nevertheless placed under the care of her son-in-law, Dr Theodor, for closer and more prolonged observation. The latter gentleman reported that he had repeatedly watched the whole process, and that the description given of it by the patient was in all points correct; he also forwarded a perfect female insect which had been extracted from the skin while he himself looked on. The insect was identified by $\mathrm{Dr} \mathrm{G}$ Joseph as belonging to the Draconidx (Hymenoptera), it was 0.6 centimetre ( 1 inch) long, and possessed two very long feelers and a sting measuring 0.5 millimetre $(0.02$ inch). Professor Fischer purposes giving a fuller description of it and its eggs, and a more detailed account of the whole case, when he has had the patient for a longer time under observation. The various remedies employed have so far produced no effect on the disease. Hymenoptera have been found as parasites in caterpillars and in rodent animals, but have not hitherto been noticed in the human subject. (British Medical fournal, 1880.) 